\title{
Relation between Ecological-Range Condition and Propor- tion of Soil-Surface Types
}

\author{
RICHARD E. ECKERT, JR., FREDERICK F. PETERSON, AND J. TIM BELTON
}

\section{Abstract}

Different kinds of A-horizon soil-surface types occur on loessmantled xerollic Orthids and Argids in the Intermountain area. Four soil-surface types were identified on sites with potential vegetation of Wyoming big sagebrush [Artemisia tridentata wyomingensis Beetle] and Thurber needlegrass [Stipa thurberiana Piper]. These surfaces occupy different microtopographic positions and have different morphologies and chemical and physical properties. This study relates differences in the cover of these soil-surface types to ecological-range condition on sites of similar potential. Proportion of the surface type found under shrub or bunchgrass cover varies with range condition. More of the surface associated with shrub cover is found on low condition sites because of greater sagebrush cover. More of the surface associated with bunchgrass cover is found on high condition sites because of greater grass cover. Proportion of the surface types found in the interspace between shrubs also varies with range condition. High condition sites have a greater cover of the soil surface associated with bunchgrass cover and of the soil surface with cryptogam-stabilized microrelief. Conversely, low condition sites have essentially none of the soil surface associated with bunchgrass cover but a large amount of the soil surface with little microrelief. Results are interpreted in terms of watershed stability and natural revegetation potential.

Various ecological sites in the Intermountain area occur on xerollic Orthids and Argids. The A horizons of many of these soils have formed in a thin loess mantle and have distinctive morphologies determined by their parent material, their microtopographic position, and recent vegetation. This loess originated from sediments deposited in large Pleistocene lakes and subsequently exposed to wind transport as the lakes dried (Young and Evans 1986). In Nevada, the area leeward of these former lakes have soils that commonly are capped with loam, very fine sandy loam, or silt loam textured surface soils. This area is informally called the Humboldt Loess Belt and comprises about 8 million ha in central and northern Nevada and extends into southeastern Oregon,

Authors are range scientist, USDA/ARS, 920 Valley Road, Reno, Nev. 89512; soil scientist, Dep. of Plant Science, Univ. of Nevada, Reno 89557; and former graduate student, Dep. of Range, Wildlife, and Forestry, Univ. of Nevada, Reno 89512 . Belton is currently a range conservationist, USDA/FS, Saugus Ranger District, Saugus, Calif. 91350.

This research is the result of cooperative investigations of the USDA-ARS and the Nevada Agr. Exp. Sta. and was funded in part by the USDI-BLM.

Manuscript accepted 26 December 1985. southern Idaho, and western Utah.

Four distinctive soil-surface morphological types of $A$ horizons are found on fan piedmonts and basin floors in the Wyoming big sagebrush [Artemisia tridentata wyomingensis Beetle]-grass vegetation types in the Humbolt Loess Belt (Eckert et al. 1977) (Fig. 1). These soil-surface types are closely related to their microtopograpic position. A schematic cross-sectional diagram and description of these microtopographic positions are presented in Figure 2 and Table 1, respectively. Similar surfaces have been recognized by Hugie and Passey (1964), Schlatterer (1968), and Stuart et al. (1971, 1973). Postulated genesis of these surface horizons and their morphological attributes such as polygon shape, morphology, vesicularity, polygon microrelief, and surface cracks between polygons have been described (Eckert et al. 1977). Texture, organic matter, bulk density, modulus of rupture, and porosity characteristics of these soil surfaces were described by Wood et al. (1978). Eckert et al. (1978), Stephens (1980), and Wood et al. (1982) have shown that these morphological and physical properties can affect plant and hydrologic responses to rangeland improvement and management practices.

Table 1. Surface soil morphological types and their microtopographic positions.

\begin{tabular}{ccl}
\hline $\begin{array}{l}\text { Surface soil } \\
\text { morphological } \\
\text { type }\end{array}$ & $\begin{array}{c}\text { Micro- } \\
\text { topographic } \\
\text { position }\end{array}$ & $\begin{array}{l}\text { Description of microtopographic } \\
\text { position }\end{array}$ \\
\hline I & Coppice & $\begin{array}{l}\text { A semi-conical form, the highest } \\
\text { microtopographic elevation. }\end{array}$ \\
II & Coppice bench $\begin{array}{l}\text { A flattish or gently sloping area next } \\
\text { highest to the coppice, and higher } \\
\text { than any adjacent intercoppice or } \\
\text { playette, if the latter occur. }\end{array}$ \\
III & Intercoppice \\
microplain & $\begin{array}{l}\text { A gently sloping or nearly flattish } \\
\text { area next lower than the coppice } \\
\text { bench. (Absent in some situations). }\end{array}$ \\
& Playette & $\begin{array}{l}\text { A slightly depressed or flat area at the } \\
\text { lowest microtopographic elevation } \\
\text { and surrounded by coppices, coppice } \\
\text { benches, or intercoppice microplains. } \\
\text { Absent in some situations). }\end{array}$ \\
& &
\end{tabular}


This study describes the relation between the areal proportions of these soil-surface types and ecological-range condition. Results are interpreted in terms of watershed stability and natural revegetation potential.

\section{Description of Soil-Surface Types}

Typically, the Type I and II surfaces have from 1 to $4 \%$ organic matter, a soft or only very slightly hard consistence, a very fine subangular blocky structure, a dry-soil infiltration rate of up to 7 $\mathrm{cm} /$ hour, a sediment-production potential of as much as 160 $\mathrm{kg} / \mathrm{ha}$, and lack of significant crusts with vesicular porosity (Blackburn 1975, Eckert et al. 1978). The Type I surface is almost always associated with cover of established vegetation on a coppice dune that accumulated under a shrub (mostly Wyoming big sagebrush in this study) or bunchgrass canopy. Type I surface is formed of round-topped, small polygons that are separated by relatively wide, trench-like, cracks and the surface is commonly covered with litter. The Type II surface is found most commonly as a margin around a Type I coppice dune. The Type II surface has pinnacled, small polygons separated by trench-like cracks. Cryptogams such as lichens and moss [Tortula ruralis (Hedw.) Gaertn., Meyer and Scherb.] stabilize this surface. Water rapidly infiltrates into Type I and II surfaces during heavy rain or snowmelt.

Typically, the Type III and IV surfaces have less than $1 \%$ organic matter and form durable crusts after wetting and drying cycles. These crusts have prominent vesicular pores and may be either massive or weakly platy. Crusts dry to slightly hard, or hard consistence and have a dry-soil infiltration rate of up to $4 \mathrm{~cm} /$ hour and a sediment-production potential of as much as $400 \mathrm{~kg} / \mathrm{ha}$ (Blackburn 1975, Eckert et al. 1978). The Type III surface forms on the short, very gentle slopes, or "microplains," that occur between and around the coppice dunes and benches on which the Type I and II surfaces occur. These microplains have also been called "shrub interspaces." The Type III surface has flat-topped, moderatelylarge polygons separated by narrow cracks. The Type IV surface has flat-topped, very large polygons separated by narrow cracks. Type III and IV surfaces are mostly barren, except for partial cryptogam cover on polygons or around polygon margins. During a heavy rain or snowmelt, water runs over the Type III surface and stands on the Type IV surface, and saturates the upper few cen-

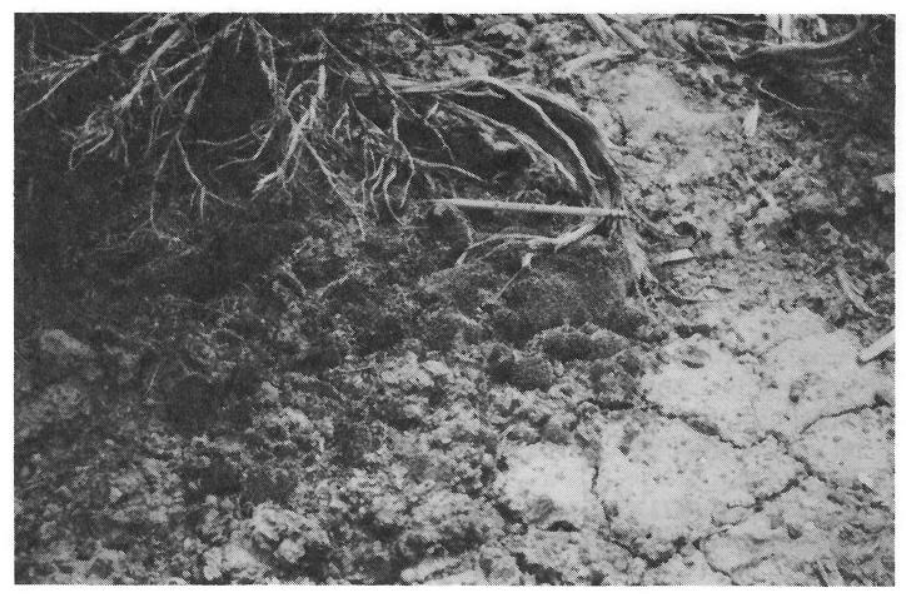

Fig. 1. Example of soil-surface types: Type I surface under the shrub and covered with moss and litter; Type II surface in lower left of photograph with small pinnacled polygons separated by trenched cracks and stabilized by cryptogam crust; and Type III surface in lower right of photograph with large, flat polygons separated by narrow cracks.

timeters of both for short periods.

\section{Methods}

The inference technique described by Tueller and Blackburn (1974) was used to choose study areas. This technique assumes that it is possible to select sites with similar enough soils, elevations, slopes, and exposures so that site potential is similar. Sixteen sites in northern Nevada were selected for this study. Nine sites are in the Sheep Creek Range north of Battle Mountain and 7 are in the Crowley Creek area of the Montana Mountains northwest of Orovada. Soils (Table 2) and remnant vegetation suggest that all sites have the potential to produce a similar kind and amount of vegetation. Therefore, differences in current vegetation and soilsurface morphological types can be interpreted as reflections of variations in management history and resultant range condition rather than as reflections of individual site factors or differences in
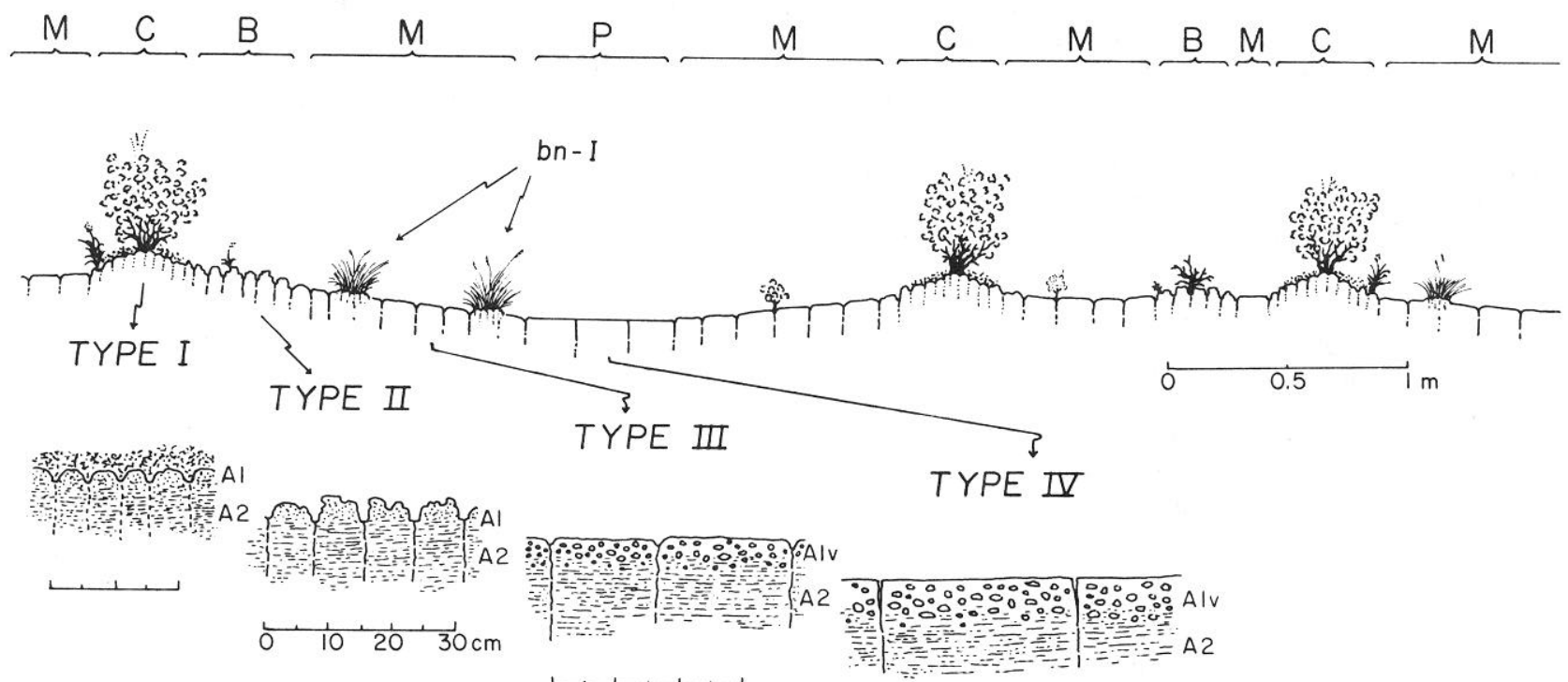

Fig. 2. Schematic cross-sectional diagram of the microtopographic positions of the 4 surface-soil types, including bunchgrass-Type I (bn-l), associated with gently sloping, shallowly loess-mantled xerollic Orthids and Argids of the Humboldt Loess Belt. Microtopographicpositions are: $C=$ coppice, $B=$ coppice bench, $M=$ intercoppice microplain, $P=$ playette. Vertical scale is somewhat exaggerated. Type I is litter covered. Circles indicate vesicles in crusts $(A l v)$. 
site potential. This argument is based on 2 main points.

(1) The kinds of soils at the study sites previously have been considered to have Wyoming big sagebrush-Thurber needlegrass [Stipa thurberiana Piper] potential vegetation. The soils, as identified at the Family level (Table 2), are among those correlated with the Loamy 8-10" and Droughty Loam 8-10" Range Sites described in the Ecological Site Descriptions for the Humboldt Area-MLRA 24 (USDA 1982). These are the only 2 range sites with Wyoming big sagebrush the dominant shrub and Thurber needlegrass the dominant grass that are identified in this Resource Area for gentle slopes and with the kinds of soils that occur at our study sites. Annual production for these range sites is estimated to differ by only 100 to $150 \mathrm{~kg} / \mathrm{ha}$. Blackburn et al. (1968) described a big sagebrush-Thurber needlegrass habitat type for the same area of the Montana Mountains sampled in the present study. Also, in southern Idaho where soils and vegetation patterns are similar to those in our study areas, Hironaka et al. (1983) described only one habitat type with Wyoming big sagebrush the dominant shrub and Thurber needlegrass the dominant understory grass.

(2) Those soil properties commonly considered to cause differences in site potential are either very similar among sites, or where different, show no regular relation to current range condition. The soil Family identification, site and soil profile characteristics, basal area of decreaser bunchgrass, and range condition class for each study site are given in Table 2 . The similarities among soils are marked. All are Aridisols and in Xerollic subgroups, therefore all sites should have about the same soil water regime. All have mesic soil temperature regimes. All have ochric epipedons with sandy loam, very fine sandy loam, or silt loam textures. Because of the thin loess cap that blankets the area, a relatively high content of very fine sand and coarse silt in the A horizons lends very similar physical behavior to these surfaces as they wet and dry to form characteristic surface morphologies. None of the sites have surface textures of the sand, loamy sand, or clay classes that are sometimes related to vegetation changes or that cannot support the morphological features of the soil-surface types studied here. There are also obvious differences in various soil and site factors among locations. To test the possible effects of differences in these factors on range condition, simple correlations were made between several of these factors and range condition as estimated by basal area of decreaser bunchgrasses. No significant correlation was found between range condition class and elevation, depth to duripan or bedrock, thickness of the A horizon, slope, or aspect ( $r^{2}$ values $<0.1$. Table 2 also shows that sites with the same particle size class are in quite different range condition classes.

This evidence strongly indicates that these soil and site factors have produced a very similar potential vegetation on all sites. Therefore, it seems reasonable to attribute differences in ecologicalrange condition of existing vegetation and related soil-surface types to different management histories.

Thurber needlegrass is the main decreaser species on all sites at each of the 2 study areas. Wyoming big sagebrush, Sandberg bluegrass [Poa sandbergii Vasey], and squirreltail [Sitanion hystrix (Nutt.) J.G.Sm.] are the principal increaser species; cheatgrass [Bromus tectorum L.] is an invader species. Important perennial forbs are desert phlox [Phlox austromontana Cov.], tapertip hawksbeard [Crepis acuminata Nutt.], Stansbury phlox [Phlox stansburyi Hel.], milkvetch [Astragalus spp. L.], wild onion

Table 2. Identification, properties of soils, and range condition classes on 16 sites in northern Nevada that have potential vezetation of Wyoming big sagebrush and Thurber needlezrass.

\begin{tabular}{|c|c|c|c|c|c|c|c|}
\hline $\begin{array}{l}\text { Location } \\
\text { and site } \\
\text { number }\end{array}$ & $\begin{array}{l}\text { Elevation } \\
\text { (m) }\end{array}$ & $\begin{array}{c}\text { Slope (\%) } \\
\text { and } \\
\text { aspect }\end{array}$ & Soil Family identification & $\begin{array}{l}\text { A horizon } \\
\text { thickness } \\
\text { (cm) }\end{array}$ & $\begin{array}{l}\text { Depth to } \\
\text { duripan or } \\
\text { bedrock } \\
\text { (cm) }\end{array}$ & $\begin{array}{c}\text { Decreaser } \\
\text { bunchgrass } \\
\text { basal area } \\
(\%)\end{array}$ & $\begin{array}{c}\text { Range } \\
\text { condition } \\
\text { class }\end{array}$ \\
\hline \multicolumn{8}{|l|}{ Crowley Creek } \\
\hline 1 & 1,448 & $3 \mathrm{E}$ & $\begin{array}{l}\text { Fine, montmorillonitic, mesic Xerollic } \\
\text { Durargid }\end{array}$ & 30 & 56 & 0.9 & Mid-seral \\
\hline 2 & 1,451 & $1 \mathbf{S W}$ & Fine-loamy, mixed, mesic Xerollic Durorthid & 25 & 46 & 0.8 & Mid-seral \\
\hline 3 & 1,463 & 2NE & $\begin{array}{l}\text { Coarse-loamy, mixed, mesic Xerollic } \\
\text { Durorthid }\end{array}$ & 13 & 39 & 0.0 & Early-seral \\
\hline 4 & 1,518 & $\mathbf{4 N W}$ & $\begin{array}{l}\text { Coarse-loamy, mixed, mesic Xerollic } \\
\text { Durorthid }\end{array}$ & 14 & 31 & 2.8 & Late-seral \\
\hline 5 & 1,524 & $3 \mathbf{N W}$ & $\begin{array}{l}\text { Coarse-loamy, mixed, mesic Xerollic } \\
\text { Durorthid }\end{array}$ & 13 & 35 & 0.2 & Early-seral \\
\hline 6 & 1,530 & $4 N W$ & $\begin{array}{l}\text { Coarse-loamy, mixed, mesic Xerollic } \\
\text { Durothid }\end{array}$ & 26 & 47 & 3.3 & Late-seral \\
\hline 7 & 1,564 & 4SE & $\begin{array}{l}\text { Coarse-loamy, mixed, mesic Xerollic } \\
\text { Durothid }\end{array}$ & 20 & 45 & 2.3 & Late-seral \\
\hline \multicolumn{8}{|l|}{ Sheep Creek } \\
\hline 8 & 1,576 & $4 \mathrm{NE}$ & $\begin{array}{l}\text { Fine-loamy, mixed, mesic Xerollic } \\
\text { Durargid }\end{array}$ & 20 & 65 & 0.0 & Early-seral \\
\hline 9 & 1,615 & $4 \mathrm{NW}$ & Coarse-loamy, mixed, mesic Xerollic Camborthid & iid 15 & $>100$ & 0.2 & Early-seral \\
\hline 10 & 1,637 & 4SE & $\begin{array}{l}\text { Fine, montmorillonitic, mesic, Xerollic } \\
\text { Durargid }\end{array}$ & 29 & 84 & 1.3 & Mid-seral \\
\hline 11 & 1,667 & 3NE & $\begin{array}{l}\text { Fine, montmorillonitic, mesic Xerollic } \\
\text { Durargid }\end{array}$ & 28 & 90 & 2.5 & Late-seral \\
\hline 12 & 1,670 & $3 N W$ & $\begin{array}{l}\text { Fine, montmorillonitic, mesic Xerollic } \\
\text { Durargid }\end{array}$ & 28 & 65 & 1.1 & Mid-seral \\
\hline 13 & 1,682 & $3 \mathbf{N W}$ & Fine-loamy, mixed, mesic Xerollic Durargid & 33 & 64 & 0.1 & Early-seral \\
\hline 14 & 1,701 & $3 \mathrm{SW}$ & $\begin{array}{l}\text { Coarse-loamy, mixed, mesic Xerollic } \\
\text { Durothid }\end{array}$ & 10 & 35 & 5.0 & $\begin{array}{l}\text { Potential- } \\
\text { natural }\end{array}$ \\
\hline 15 & 1,704 & $2 \mathrm{NW}$ & Coarse-loamy, mixed, mesic Xerollic Durorthid & 27 & 43 & 0.0 & Early-seral \\
\hline 16 & 1,722 & $2 \mathrm{NW}$ & $\begin{array}{l}\text { Fine, montmorillonitic, mesic Xerollic } \\
\text { Haplargid }\end{array}$ & 19 & $>100$ & 4.3 & $\begin{array}{l}\text { Potential- } \\
\text { natural } \\
\text { community }\end{array}$ \\
\hline
\end{tabular}




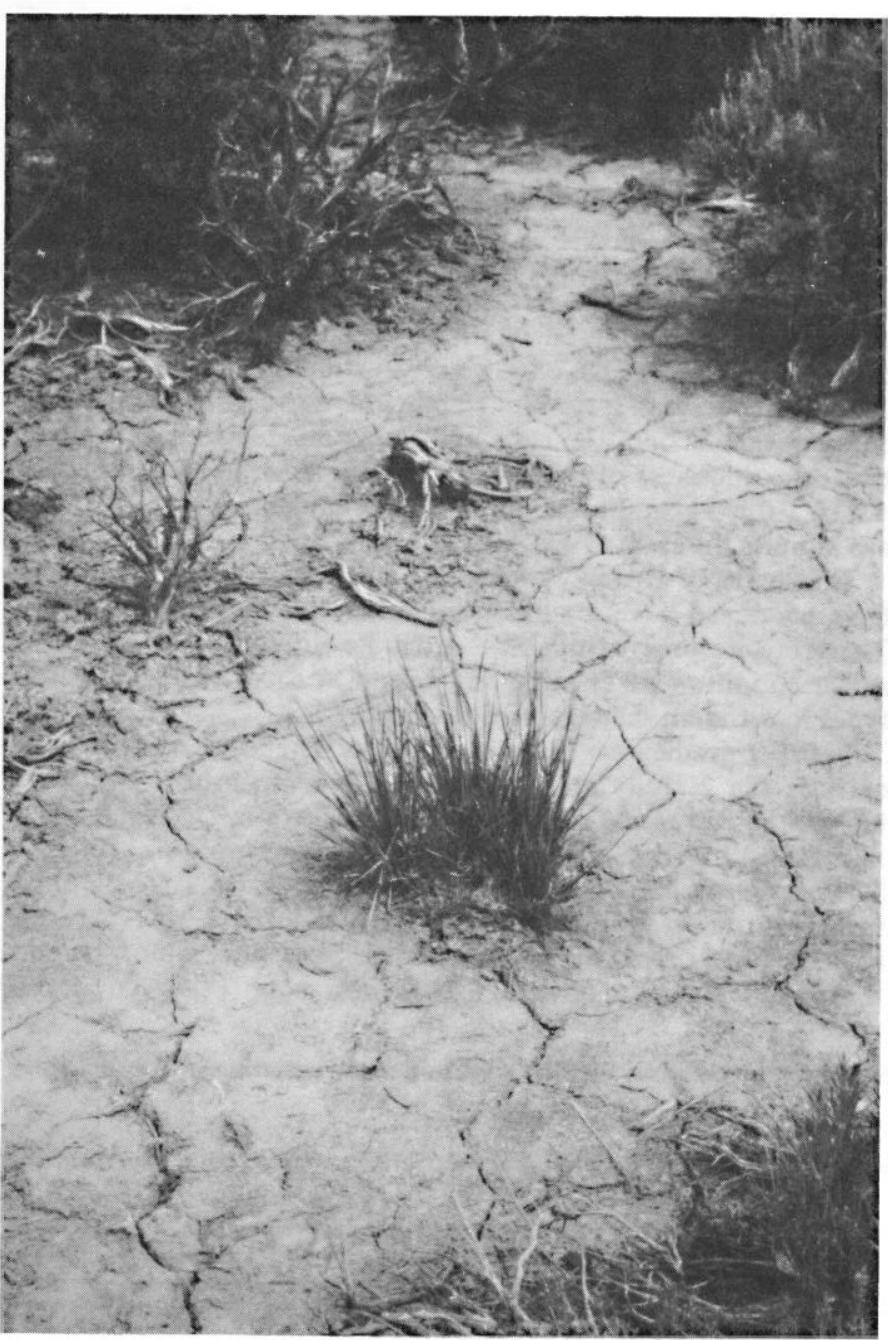

Fig. 3. Perennial grass plant with a bunchgrass-Type I surface growing on a Type IV surface.

[Allium spp. L.], and fleabane [Erigeron spp. L.]. Many annual forbs are present on disturbed sites. Elevation of the sites ranges from 1,448 to $1,722 \mathrm{~m}$, and slope varies from 1 to $4 \%$.

Vegetation on each study area was stratified on the basis of abundance of Thurber needlegrass. Within each stratum, a study site of $30 \times 100 \mathrm{~m}$ was randomly located in a homogenous stand of vegetation. Canopy cover of shrubs and surface cover soil-surface types were estimated by the line-intercept method (Canfield 1941) on 10 randomly selected $30-\mathrm{m}$ transects. In addition to the 4 soil surface types described earlier, a bunchgrass-Type I surface was also identified (Figs. 2 and 3) and measured separate from the shrub-Type I surface. Recognition of a bunchgrass-Type I surface is important from a hydrologic standpoint because the soil under bunchgrass has a high infiltration capacity (Blackburn 1975). Since the Type IV surface was found only on 2 of 16 sites with an average cover of less than $3 \%$ on these 2 sites, data for this surface were combined with those for the Type III surface for presentation of results. Basal-area cover of perennial bunchgrasses was estimated with the aid of guide rings of known areas on $10,30 \times 60 \mathrm{~cm}$ microplots placed systematically along each transect line.

Significant $(P \leq 0.05)$ differences among the various vegetation and soil-surface type attributes were determined by analysis of variance and Duncan's multiple range test.

\section{Results and Discussion}

Vegetation on each of the 16 study sites was placed in 1 of 4 ecological-range condition classes based on significant differences in the basal-area cover of decreaser grasses, mainly Thurber needlegrass (Table 3). Two sites have the potential-natural community (PNC); 4 sites are in late-seral condition; 4 sites are in mid-seral condition, and 6 sites are in early-seral condition. Mean basal area of Thurber needlegrass $(2.7 \%)$ on sites in late-seral condition is similar to that found on high condition sites representing the Wyoming big sagebrush-Thurber needlegrass habitat type in southern Idaho (personal communication, M. Hironaka). The Nevada sites with a greater mean basal cover of needlegrass $(4.6 \%)$ may represent an even higher condition class than that described in Idaho. The range condition terminology used is that proposed by the Range Inventory Standardization Committee (1983). PNC, and late-, mid-, and early-seral classes are equivalent to the excellent, good, fair, and poor classes, respectively, as defined by the Soil Conservation Service (1976) and used to compare present vegetation with potential vegetation.

The proportion of each soil-surface type varies with ecologicalrange condition (Table 3 ). Total cover of Type I surface is related to the cover of shrub-Type I and bunchgrass-Type I surfaces and is greatest on sites in either early- or late-seral condition. The cover of bunchgrass-Type I surface is from 3 to 9 times greater on sites with PNC than on sites in lower seral stages. The basal area of decreaser grasses and bunchgrass-Type I surface varies concomitantly with range condition, but basal area of increaser grasses does not vary with range condition. This response suggests that formation of a bunchgrass-Type I surface is more dependent on the presence of decreaser grasses than on increaser grasses. Longevity of decreaser grasses, amount of litter deposited, litter quality, and root characteristics may be responsible for development and maintenance of a bunchgrass-Type I surface.

Bunchgrass-Type I, Type II, and Type III surfaces vary more with range condition than do shrub-Type I or total-Type I surfaces (Table 3). Not only does the extent of the former surfaces vary with range condition, but so does the spatial distribution pattern. Previous studies of other sites in early-seral condition (Eckert et al.

Table 3. Mean vegetation and soil-surface characteristics associated with 4 range condition classes on sites in northern Nevada with potential vegetation of Wyoming big sagebrush and Thurber needlegrass.

\begin{tabular}{|c|c|c|c|c|c|c|c|c|c|}
\hline \multirow[b]{2}{*}{$\begin{array}{l}\text { Ecological-range } \\
\text { condition and } \\
\text { number of sites }\end{array}$} & \multicolumn{4}{|c|}{$\begin{array}{c}\text { Vegetation characteristics } \\
(\% \text { Cover })\end{array}$} & \multicolumn{5}{|c|}{$\begin{array}{c}\text { Soil-surface characteristics } \\
\text { (\% Surface cover) }\end{array}$} \\
\hline & $\begin{array}{l}\text { Canopy, } \\
\text { big } \\
\text { sagebrush }\end{array}$ & $\begin{array}{c}\text { Basal, } \\
\text { decreaser } \\
\text { grasses }\end{array}$ & $\begin{array}{c}\text { Basal, } \\
\text { increaser } \\
\text { grasses }\end{array}$ & $\begin{array}{c}\text { Basal, total } \\
\text { perennial } \\
\text { grasses }\end{array}$ & $\begin{array}{l}\text { Shrub- } \\
\text { Type I }\end{array}$ & $\begin{array}{l}\text { Bunchgrass- } \\
\text { Type I }\end{array}$ & $\begin{array}{l}\text { Total- } \\
\text { Type I }\end{array}$ & Type II & Type III \\
\hline $\begin{array}{r}\text { Potential natural } \\
\text { community (2) }\end{array}$ & $16 \mathrm{~b}^{1}$ & & & & & & & & \\
\hline Late-seral (4) & $18 \mathrm{~b}$ & $\begin{array}{l}4.0 \mathrm{a} \\
2.7 \mathrm{~b}\end{array}$ & $\begin{array}{l}2.6 \mathrm{a} \\
3.3 \mathrm{a}\end{array}$ & $\begin{array}{l}7.2 \mathrm{a} \\
6.0 \mathrm{ab}\end{array}$ & $\begin{array}{l}21 \mathrm{~b} \\
32 \mathrm{a}\end{array}$ & $\begin{array}{l}9 \mathrm{a} \\
3 \mathrm{~b}\end{array}$ & $\begin{array}{l}30 \mathrm{ab} \\
35 \mathrm{a}\end{array}$ & $\begin{array}{l}61 \mathrm{a} \\
44 \mathrm{~b}\end{array}$ & $\begin{array}{r}9 \mathrm{c} \\
21 \mathrm{~b}\end{array}$ \\
\hline Mid-seral (4) & $22 \mathrm{ab}$ & $1.0 \mathrm{c}$ & $3.3 \mathrm{a}$ & $4.3 \mathrm{~b}$ & $29 a$ & $1 \mathrm{bc}$ & $30 \mathrm{~b}$ & $45 \mathrm{~b}$ & $25 \mathrm{~b}$ \\
\hline Early-seral (6) & $26 a$ & $\mathrm{~T}^{2} \mathrm{~d}$ & $2.1 \mathrm{a}$ & $2.2 \mathrm{c}$ & $33 \mathrm{a}$ & $\mathrm{T} \mathrm{c}$ & $33 \mathrm{a}$ & $32 \mathrm{c}$ & $35 \mathrm{a}$ \\
\hline
\end{tabular}

'Means in the same column followed by different letters are significantly different $(P \leq 0.05)$ as determined by Duncan's multiple range test. ${ }^{2} \mathrm{~T}=<1 \%$ basal area or soil-surface cover. 
1977) reported the Type I surface only on coppice dunes under shrub canopies, and the Type II surface only adjacent to the Type I surface (Fig. 2) and not on the microplains of the shrub interspaces. In the present study, basal cover of bunchgrass in the interspaces among shrubs is greater on sites in PNC and late-seral condition than on sites in lower range condition. Since each bunchgrass plant has a Type I surface at its base, this bunchgrass-Type I surface is more extensive in the interspaces of high condition sites than of low condition sites. Also on high condition sites in the present study, the Type II surface forms patchy, cryptogam-stabilized areas on the microplains in shrub interspaces. Less of the Type II surface occurs on the microplain of low condition sites.

\section{Data Interpretation and Implications}

Based on the data presented, we propose a scenario of how proportions of soil-surface types might change as range condition varies from PNC to early-seral condition and how these changes may affect the hydrologic and natural revegetation characteristics of a site.

Sites with PNC have a surface covered mostly with shrub-Type I, bunchgrass-Type I, and Type II surfaces. These soil surfaces have favorable hydrologic characteristics because of fine-subangular blocky or weak platy structure and few vesicular pores (Loope and Gifford 1972, Blackburn 1975). Their common depression microsites and friable soil may also favor natural revegetation (Harper et al. 1965, Eckert et al. 1978, Stephens 1980). Since bunchgrass Type I and Type II surfaces occur on microplains in shrub interspaces as well as on coppice dunes under shrubs and on coppice benches around shrubs, beneficial hydrologic and revegetation effects are spread more or less uniformly across the site. Furthermore, sites with PNC have a very small coverage of Type III surface with its unfavorable hydrologic and revegetation characteristics that are due to massive structure and smooth surface crusts with vesicular porosity.

On sites in late- and mid-seral condition, cover of total Type I surface is about the same as on sites with PNC because shrub canopy cover is similar. Therefore, hydrologic and revegetation characteristics associated with shrub-Type I surface are similar to that on sites with PNC. Bunchgrass-Type I surface is less than on sites with PNC because basal cover of decreaser grasses is less. Cover of Type II surface also is less because of the physical destruction of this rough, cryptogam-stabilized surface by livestock hoof action (Anderson et al. 1982). After repeated heavy trampling this surface is crushed into a smooth Type III surface. With less bunchgrass-Type I and Type II surfaces, the proportion of Type III surface is greater and fewer sites for rapid infiltration occur in the interspaces. Water moves more rapidly over a smooth crusted surface with vesicular pores and, with lower infiltration, runoff and sediment-production potential should increase. In addition to unfavorable hydrologic characteristics, unfavorable revegetation characteristic for desirable species also are associated with the microrelief and morphological features of the Type III surface (Stephens 1980). In spite of these undesirable changes, secondary succession should still be possible on sites in late- and mid-seral range condition because these sites have remnants of decreaser grasses and Type I and II soils cover more than $75 \%$ of the surface. Thus a network of microsites is available for potential establishment of new plants of desirable species provided grazing management maintains plant vigor and seed production by these species.

On sites in early-seral range condition, sagebrush canopy cover, cover of shrub- Type I, total-Type I, and Type III soil surfaces are generally greater than on sites in higher range condition. Bunchgrass-Type I surface is much less extensive because of a lack of decreaser bunchgrasses. Cover of Type II surface is further reduced by trampling. All of the favorable hydrologic and revegetation characteristics associated with the shrub-Type I surface should have about maximum expression because of the large proportion of this surface type on early-seral sites. Conversely, all of the negative hydrologic and revegetation characteristics associated with the Type III surface also should have about maximum expression because of the large proportion of this surface type on sites in early-seral range condition. Even on sites in early-seral condition, however, Type I and II soils still cover $65 \%$ of the surface and provide a number of possible microsites for seedling establishment and natural revegetation. Unfortunately, decreaser grasses are very scarce or lacking and produce little or no seed to utilize the available microsites. Even increaser grasses lack vigor and have reduced seed production due to heavy grazing and competition from sagebrush. These vegetation and soil-surface conditions appear to perpetuate sagebrush, cheatgrass and annual forbs - a condition we see all too often in the Intermountain area.

\section{Conclusions}

On rangelands in northern Nevada with a potential vegetation of Wyoming big sagebrush and Thurber needlegrass, sites managed to maintain PNC should have the most favorable watershed characteristics due to a large proportion and even distribution of soil surfaces with favorable hydrologic traits. Also, if an opening in the community occurs, seed of desirable species should have a large number of microsites available for potential plant establishment and perpetuation of the species.

Sites in late- and mid-seral range condition also have a large number of favorable microsites due to microrelief of the soil surfaces. Grazing management should be designed to enhance vigor and seed production of desirable species in order to increase the density and widen the spatial distribution of plants of these species. Watershed quality has been somewhat diminished because of the reduced extent and uneven distribution of soil surfaces with favorable hydrologic characteristics and increased amount of the soil surface with unfavorable hydrologic characteristics.

Sites in early-seral condition have a few or no decreaser grasses, a dense cover of big sagebrush, and a large proportion of a soil surface with both unfavorable hydrologic qualities and with microsites that appear to encourage establishment of sagebrush, cheatgrass, and weedy annual forbs. These sites cannot be improved by grazing management alone. Rather, brush and weed control, and seeding with adopted species are required to increase forage production and improve watershed conditions.

\section{Literature Cited}

Anderson, D.C., K.T. Harper, and R.C. Holmgren. 1982. Factors influencing development of cryptogamic soil crusts in Utah deserts. J. Range Manage. 35:180-185.

Blackburn, W.H., P.T. Tueller, and R.E. Eckert, Jr. 1968. Vegetation and soils of the Crowley Creek Watershed. R 42. Univ. of Nevada College of Agr., Reno.

Blackburn, W.H. 1975. Factors influencing infiltration rate and sediment production of semiarid rangelands in Nevada. Water Resources Research 11:929-937.

Canfield, R.H. 1941. Application of the line interception method in sampling range vegetation. J. Forest. 39:388-394.

Eckert, R.E., Jr., F.F. Peterson, M.K. Wood, and W.H. Blackburn. 1977. Properties, occurrence, and management of soils with vesicular surface horizons. Final Report, Contract 520-CT5-(N) between the USDI, Bureau of Land Management and the Nevada Agr. Exp. Sta.

Eckert, R.E., Jr., M.K. Wood, W.H. Blackbum, F.F. Peterson, J.L. Stephens, and M.S. Meurisse. 1978. Effects of surface-soil morphology on improvement and management of some arid and semiarid rangelands. Proc. First Internat. Range. Cong., Denver, Colo.

Harper, J.L., J.T. Williams, and G.R. Sanger. 1965. The behavior of seed in soil. I. The heterogeneity of soil surfaces and its role in determining the establishment of plants. J. Ecol. 53:273-286.

Hironaka, M., M.A. Fosberg, and A.H. Winward. 1983. Sagebrush-grass habitat types in southern Idaho. College of Forestry, Wildlife, and Range Science, Univ. of Idaho, Moscow. Bull. No. 35.

Hugle, V.K., and H.B. Passey. 1964. Soil surface patterns of some semiarid soils in northern Utah, southern Idaho, and northeastern Nevada. Soil Sci. Soc. of Amer. Proc. 28:786-792. 
Loope, W.L., and G.F. Gifford. 1972. Influence of a soil microfloral crust on select properties of soils under pinyon-juniper in southeastern Utah. J. Soil and Water Conserv. 27:164-167.

Range Inventory Standardization Committee. 1983. Guidelines and terminology for range inventories and monitoring. Soc. for Range Manage., Denver, Colo.

Schlatterer, E.F. 1968. Establishment and survival of three native grasses under natural and artificial conditions. Ph.D. Thesis, Univ. of Idaho. Moscow.

Stephens, J.L. 1980. Seedling emergence on vesicular crusted surfaces as affected by artificial and natural cattle trampling. M.S. Thesis, Univ. of Nevada, Reno.

Stuart, D.M., G.E. Schuman, and A.S. Dylla. 1971. Chemical characteristics of coppice dune soils in Paradise Valley, Nevada. Soil Sci. Soc. of Amer. Proc. 35:607-611.

Stuart, D.M., R.E. Eckert, Jr., A.S. Dylla, and G.E. Schumnn. 1973. Seeding coppice dune areas in northern Nevada. Agr. Exp. Sta., Univ. of Nevada, Reno and USDA/ARS-WR Tech. Bull. T II.
Tueller, P.T., and W.H. Blackburn. 1974. Condition and trend on the big sagebrush/needle and thread habitat type in Nevada. J. Range Manage. 27:36-40.

USDA. 1976. National Range Handbook. Soil Conservation Service, Washington, D.C.

Wood, M.K., W.H. Blackburn, R.E. Eckert, Jr., and F.F. Peterson. 1978. Interrelations of the physical properties of coppice dune and vesicular dune interspace soil with grass seedling emergence. J. Range Manage. 31:189-192.

Wood, M.K., R.E. Eckert, Jr., W.H. Blackburn, and F.F. Peterson. 1982. Influence of crusting soil surfaces on emergence and establishment of crested wheatgrass, squirreltail, Thurber needlegrass, and fourwing saltbush. J. Range Manage. 35:282-287.

Young, J.A., and R.A. Evans. 1986. Erosion and deposition of fire sediments from playas. J. Arid Environ. 10:103-115.

USDA. 1982. Ecological site descriptions, Humbolt Area, MLRA 24, Soil Conserv. Serv. Reno, Nevada, Mimeo. 